\title{
Strictly Avoiding Four Styles of Work, Enhancing the Level of Teaching: Frontline Teachers at Universities and Colleges Saying No to Four Styles of Work
}

\author{
Yun LI, Ying WU, Dandan ZHAO, Qi REN, Peng YANG \\ School of public health, Hebei United University
}

\begin{abstract}
Four styles of work not only affect the Party's work, but also affect the improvement of the quality of the frontline teachers at universities and colleges and the improvement of teaching quality. This paper conducts an in-depth analysis of the four styles of work existing in the frontline teachers at universities and colleges and their impact. And appropriate corrective measures and methods are proposed, which is not only conducive to the development of teachers themselves, but also conducive to the improvement of teaching standards, helping to train talents, thus promoting the healthy development of society and science.
\end{abstract}

KEYWORD: Four styles of work; teaching; universities and colleges

In 2013, Xi Jinping, General Secretary of the Communist Party of China, State President and Chairman of CMC delivered an important speech at the Party's mass line educational practice conference, emphasized the main task of the educational practice focusing on the construction of working style, focusing on solving the four styles of work of formalism, bureaucracy, hedonism and extravagance [1]. As the frontline teachers at universities and colleges, deep analysis of the four styles of work existing in their own, strict avoidance of the four styles of work not only helps to improve teachers' own quality and ideological awareness, and helps to improve the teaching level and the quality of students as well.

\section{PAYING ATTENTION TO THE EFFECTIVENESS OF THE WORK, SAYING NO TO THE STYLE OF FORMALISM}

Formalism refers to the style of putting one-sided emphasis on form regardless of the practice, or the thinking of just thinking highly of the phenomenon rather than analyzing and the essence [2]. Formalism in the frontline teachers at universities and colleges is mainly reflected in the completion of the task, less focusing on the effectiveness. Part of the frontline teachers at universities and colleges are accustomed to the completion of various tasks and requirements step by step assigned by upper-level management, without deeply thinking the reasons, lacking a thorough understanding of the work, resulting in work only being completed in a mere formality, which cannot really improve their quality of teachers.

As the frontline teachers at universities and colleges, it is crucial to improve teachers' quality so as to guarantee the teaching level. It is common for college teachers, especially young teachers to lack the classroom teaching experience, their teaching effect is not ideal, so they need badly to improve their own quality and the teaching level through various training, lectures. In daily work, they should pay more attention to the effectiveness of the work, not only taking the completion of the task as the goal, focusing only on the surface of the work; instead, they should pay attention to the effectiveness of the work, take in-depth understanding of the task, rigorously accomplish all the tasks and requirements assigned by the management, so as to improve their own quality, complete the teaching work with full spirit and good attitude, and to improve the teaching level.

\section{BUREAUCRACY}

Bureaucracy is the separation from reality and the masses, acting as master of leadership; the substance is haunted by thoughts of feudal remnants [3]. The bureaucracy in the frontline teachers at universities and colleges is reflected mainly in the phenomenon of classroom teachers responsible only for the explanation of individual knowledge; not taking the initiative to care about students. The biggest 
difference among universities and primary school, middle school is that the independence of the students, students of universities and college are usually less restrained by teachers, they have a lot of free time. Teachers in colleges and universities are also different from the middle school, primary school teachers in the aspect of working mode, some teachers tend to give large-class lectures with many students, it is difficult for them to completely remember the students, the intersection with students after class is less, resulting in a lack of smooth communication and exchanges between students and teachers, the teachers do not fully understand the knowledge needs of students, cannot understand the psychology of students, which in a certain extent, affects the relationship between teachers and students, and affects the enthusiasm of students' active learning and teaching effect as well.

Active and healthy emotions can effectively enhance human intellectual activity, enable students to be energetic, quick in thinking and have strong willpower, and active and rich imagination, and strengthening memory. The students' intellectual potential will get efficient play [4]. As the frontline teachers at universities and colleges, being closely concerned with students not only means to fully understand the ideas and needs of students, and coordinate the relationship between teachers and students, but also to promote the upgrading of teaching efficiency. Therefore, the frontline teachers at universities and colleges should also take the initiative to care about the students in their daily work, timely understand students 'ideological and psychological changes, understand the possible factors that affect students' learning attitudes, and thus enhance the teaching efficiency.

\section{HEDONISM}

Hedonism is in essence the recession of revolutionary will, reduction of spirit of struggle, which is rooted in the incorrectness of world outlook, outlook on life, and value [5]. The hedonism in frontline teachers at universities and colleges is mainly reflected in their complacency, lack of innovation consciousness. Part of the frontline teachers at universities and colleges are satisfied with what has been achieved, the existing knowledge and insights, they lack the consciousness of keeping pace with the times, pioneering and innovation, leading to outdated teaching methods and teaching content, the lack of the latest developments in related fields, and affecting the teaching efficiency. In addition, part of the frontline teachers at universities and colleges are busy with the daily work, lack the in-depth systematic thinking of their own overall development and long-term planning, they lack the pursuit of the goal, do not form a clear direction and development ideas, leading to a lack of passion for the work of teachers, not completing the teaching work with high quality, affecting the teaching level.

Pioneering and innovation is the driving force of school development, and is also the source of improving the teaching quality [6]. The frontline teachers at universities and colleges should be brave in pioneering and innovation, keep pace with the times, and constantly improve their teaching level and scientific research ability in addition to completing their job. They constantly improve themselves by contrasting school performance appraisal target, they check and examine their own gap between the work and the targets, formulate improvement measures, and constantly improve themselves. In addition, they can also improve the teaching level and teaching efficiency through continuous research and learning new teaching methods and means.

\section{EXTRAVAGANCE}

The extravagance in essence is the reflection of the ideology of the exploiting classes and decadent lifestyle, rooted in the corruption of mind, expansion of the materialism [7]. Extravagance in the frontline teachers at universities and colleges is mainly reflected in the lack of the spirit of work hard and weak sense of thrift. Part of the teachers at universities and colleges fear hardship, or labor; pay more attention to the interests, they don't want to sacrifice, dedication, they put emphasis on work conditions, and interests. And some teachers may lack the economical thought in the use of special funds, or turn a blind eye to others' waste phenomenon, they cannot stop them in time, which is difficult provide a good education environment for the students.

"Looking through the history of countless insight, no matter it is country or family, and their success is because of being hard work, thrift, and when they are extravagant and corruptible, it is the time for them to ruin." The quality of hard work and thrift has a pivotal role in the promotion of the harmonious development of the nation, and even the whole society. As the talent pool of country's future development, universities and colleges should vigorously promote the national spirit of thrift and hard work, "National Medium- and Long-Term Plan for Education Reform and Development (20102020) " also clearly pointed to "adhering to the management of the school diligently and thriftily, prohibiting extravagance, and building a conservation-oriented school." The frontline teachers at universities and colleges should firmly establish the concept of hard work, practice strict economy and combat waste, adhere to the tradition of thrift, be 
proactive at work, eager to dedicate, be economical in the use of office expenses, and at the same time, they should save water, electricity, office paper, create an educational environment so that students can have good quality of being thrift, hard working.

All in all, the four styles of work have become one of the main factors affecting their quality and teaching level of the frontline teachers at universities and colleges, if a radical cure cannot be offered, they will seriously affect the teaching efficiency and the quality of student. The frontline teachers at universities and colleges should resolutely eliminate these unhealthy styles and do not have unhealthy trends eroding our good tradition. To improve the quality of teaching and teachers themselves, we must say no to the four styles of work, which is not only conducive to the development of teachers themselves, but also help to improve teaching level, conducive to the training of the talents, thus promoting the healthy development of the society and sciences, and promoting the lasting social harmony, and ultimately realizing the victories in building a moderately prosperous society.

\section{REFERENCES}

[1] Editorial Department of Literature Garden of Party History, 2013. Xi Jinping: Focusing on solving the formalism, Bureaucracy, Hedonism and Extravagance. Literature Garden of Party History (Documentary Version), (7): 1.

[2] Hu X.P. 2014. A Tentative Study on the Manifestations, Causes and Prevention Strategies of Formalism, Journal of Huaihai Institute of Technology (Social Science Edition), (1):12-14.

[3] Sun Y.C. 2014. Discussion on Hazards of the Bureaucracy and Formalism in the Teaching Management of School. New Campus (Second Ten-day) (1):191.

[4] Wang H.Y, 2011. Paying Attention to the Student Emotion, Improving Teaching Quality. Shaanxi Education: Administrative Version, (11):18.

[5] Xu S.Y.2014. Four misunderstandings must be eliminated to oppose hedonism and extravagance. Seek Truth from Facts (2):69-71.

[6] Zhang J.G.2013. Exploration and Innovation, and Promotion of the Sustainable Development of Continuing Education. Modern Education, (7):75.

[7] Hong S.T.2013. Practice of Strict Economy, Opposition of Extravagance. Zhejiang Land and Resources, (9):15-16. 